\title{
Titrated Total Intravenous Anaesthesia (TIVA) in War
}

\author{
A Bačić \\ $\mathrm{MD}, \mathrm{PhD}$ \\ Department of Anaesthesia, Clinical Hospital Split, Spinčićeva 1, 21000 Split, Croatia
}

\section{Glunčić}

$\mathrm{MD}$

ENT Department, Clinical Hospital Split, Spinčiceva, 1, 21000 Split, Croatia

\author{
J Buklijaš \\ MD
}

Department of Anaesthesia, Clinical Hospital Split, Spinčiceva 1, 21000 Split, Croatia

SUMMARY: In the Rama mobile war hospital, intravenous (IV) anaesthesia was used in 78 patients undergoing surgical procedures lasting 4-25 min. Boluses of thiopentone (Group 1), propofol (Group 2), propofol + alfentanyl (Group 3), and ketamine + midazolam (Group 4) were used. Induction of anaesthesia, resulted in a mean blood pressure decreased about $15 \%$. Apnoea of more than 20 sec was observed in Group 3, but no naloxone was required. Recovery was rapid enabling patients to maintain their own airway. The use therefore of titrated anaesthetics in war is considered acceptable.

\section{Introduction}

At the beginning of the war in 1991 the Croatian Medical Corps Headquarters was formed to provide health care for both soldiers of the newly formed Croatian Army and civilians in Croatia, and parts of Bosnia and Herzegovina $(1,2)$.

A number of mobile war hospitals were formed to provide frontline resuscitation and surgery for the wounded in Dalmatia (South Croatia) and the neighbouring parts of Bosnia and Herzegovina. The Split Clinical Hospital provided Field Surgical Teams (FSTs) and medical supplies to the mobile units and admitted the severely wounded for further treatment.

All emergency procedures excluding neurosurgical cases were performed in mobile hospitals using either inhalation anaesthetics (halothane, nitrous oxide) and/or IV anaesthetics (fentanyl, alfentanyl, thiopentone, propofol and ketamine).

We report on titrated intravenous anaesthesia for quick surgical procedures taking 4-25 min, at the Rama mobile war hospital (3).

\section{Patients and Methods}

At the Rama war hospital near Prozor, Bosnia and Herzegovina, anaesthesia was provided for 674 wounded soldiers and civilians. Of these 78 patients, anaesthesia was maintained by titrated intravenous anaesthetics for procedures lasting 4-25 min. The patients were males, aged 19-43, ASA grade I and II. No patients received a premedication. First a vein on the dorsum of the hand was cannulated, although in 7 patients this could not be inserted due to injury to the upper extremity. In these cases the external jugular or a lower extremity vein was cannulated. Fluid resuscitation was started. Pulse, bloo pressure, and oxygen saturation were monitored. Blood pressure and pulse were also monitored before inductior as well as during and after anaesthesia.

The patients were divided into four groups according to the anaesthetic administered. Thiopentone $(3-5 \mathrm{mg} / \mathrm{kg}$ was used in eight patients (Group 1), propofol $(2.5 \mathrm{mg} / \mathrm{kg}$ ) in 12 patients (Group 2), alfentanyl in a bolus dose of 10 $15 \mu \mathrm{g} / \mathrm{kg}+$ propofol $(2.5 \mathrm{mg} / \mathrm{kg}$ ) in 49 patients (Group 3), and ketamine $(3.5 \mathrm{mg} / \mathrm{kg}$ b.w.) + midazolam $(5 \mathrm{mg})$ in nine patients with low blood pressure on admission (Group 4). Further doses of alfentanyl, propofol and ketamine were titrated to the response required. Atropine (0.5-1.0 mg) was administered for bradycardia.

\section{Results}

Seventy eight patients underwent surgical procedures lasting less than 25 minutes and data for these patients are shown in Table 1. Propofol anaesthesia was used in $78.2 \%$ of the 78 patients.

The reasons for surgery are listed in Table 2 . The majority of the patients had suffered injuries to the lower extremities. Table 3 shows the mean duration of anaesthesia and time to full recovery. The shortest duration of anaesthesia was recorded in the thiopentone group, and the longest in the alfentanyl and propofol group. The recovery from anaesthesia was the longest with ketamine. There was no significant haemodynamic changes in any groups (Table 4). Apnoea following anaesthesic induction is shown in Table 5. Apnoea of more than $20 \mathrm{sec}$ was most frequently observed in Group 
3 (alfentanyl + propofol). The occurrence of postoperative morbidity (vomiting, dreams) was most frequent in Group 4 (ketamine) (Table 6). There were no deaths during the study.

Table 1

General data of 78 male patients anaesthetised with titrated intravenous anaesthesia

\begin{tabular}{llllll}
\hline Group & & $\begin{array}{l}\mathbf{1} \\
\text { Thiopentone }\end{array}$ & $\begin{array}{l}\mathbf{2} \\
\text { Propofol }\end{array}$ & $\begin{array}{l}\mathbf{3} \\
\text { Propofol+ } \\
\text { alfentanyl }\end{array}$ & $\begin{array}{l}\text { Ketamine + } \\
\text { midazolam }\end{array}$ \\
\hline $\mathrm{N}$ & $(\%)$ & $8(10.3)$ & $12(15.4)$ & $49(62.8)$ & $9(11.5)$ \\
Weight & $(\mathrm{kg})$ & $63-84$ & $82-88$ & $59-94$ & $75-87$ \\
Age & (yrs) & $21-25$ & $20-44$ & $19-39$ & $27-34$ \\
\hline
\end{tabular}

Table 2

Reasons for Surgery

\begin{tabular}{lc}
\hline Injuries to lower extremities & 43 \\
Injuries to upper extremities & 11 \\
Injuries to gluteal region & 6 \\
Head injuries & 4 \\
Chest injuries & 6 \\
Perianal abscesses & 8 \\
Total & 78 \\
\hline
\end{tabular}

Table 3

Duration of anaesthesia and recovery

\begin{tabular}{lllll}
\hline $\begin{array}{l}\text { Duration } \\
\text { (min) }\end{array}$ & Thiopentone & Propofone & $\begin{array}{l}\text { Propofol + } \\
\text { alfentanyl }\end{array}$ & $\begin{array}{l}\text { Ketamine }+ \\
\text { midazolam }\end{array}$ \\
\hline Operation & 4 & 5 & $14(8-25)$ & $12(5-15)$ \\
Recovery & $7(5-9)$ & 6 & $8(10-15)$ & $25(17-35)$ \\
\hline
\end{tabular}

Table 4

Mean values of blood pressure and pulse during surgery

\begin{tabular}{|c|c|c|c|c|c|c|c|c|}
\hline \multirow[t]{2}{*}{ Group } & \multicolumn{2}{|c|}{1} & \multicolumn{2}{|c|}{2} & \multicolumn{2}{|c|}{3} & \multicolumn{2}{|c|}{4} \\
\hline & BP & $\mathbf{P}$ & $\mathbf{B P}$ & $\mathbf{P}$ & BP & $\mathbf{P}$ & BP & $\mathbf{P}$ \\
\hline $\begin{array}{l}\text { Before } \\
\text { anaesthes }\end{array}$ & $127 / 75$ & 88 & $135 / 80$ & 84 & $130 / 80$ & 86 & $80 / 60$ & 110 \\
\hline
\end{tabular}

2 min after

$\begin{array}{lllllllll}\text { induction } & 115 / 70 & 93 & 125 / 75 & 84 & 125 / 70 & 80 & 85 / 60 & 110\end{array}$

$\begin{array}{lllllllll}5 \text { min after } & & & & & & & & \\ \text { induction } & 115 / 70 & 84 & 125 / 75 & 84 & 120 / 75 & 80 & 95 / 70 & 100\end{array}$

\begin{tabular}{lllll}
\hline $\begin{array}{l}10 \text { min after } \\
\text { induction }\end{array}$ & $130 / 75$ & 80 & $95 / 70$ & 100 \\
\hline 15 min after induction & $120 / 80$ & 80 & $95 / 70$ & 98 \\
\hline
\end{tabular}

BP $=$ Blood Pressure

$\mathrm{P}=$ Pulse
Table 5

Number of patients with apnea

\begin{tabular}{lccc}
\hline $\begin{array}{l}\text { Anaesthesia } \\
\text { induced by }\end{array}$ & Apnea $\mathbf{2 0}$ sec & Apnea<20 sec & No apnea \\
\hline $\begin{array}{l}\text { Thiopentone } \\
\text { Propofol }\end{array}$ & 0 & 3 & 4 \\
\hline $\begin{array}{l}\text { Alfentanyl+ } \\
\text { propofol }\end{array}$ & 1 & 4 & 28 \\
$\begin{array}{l}\text { Ketamine+ } \\
\text { midazolam }\end{array}$ & 0 & 9 & 0
\end{tabular}

Table 6

Postoperative side effects

\begin{tabular}{lccccc} 
Side effect Thiopentone & Propofol & $\begin{array}{c}\text { Propofol+ } \\
\text { alfentanyl }\end{array}$ & $\begin{array}{l}\text { Ketamine+ Total } \\
\text { midazolam }\end{array}$ \\
\hline Vomiting & 1 & 0 & 6 & 2 & 9 \\
Dreams & 0 & 0 & 2 & 2 & 4 \\
\hline
\end{tabular}

Discussion

The Rama mobile hospital near Prozor was located in factory basement (3). The operating room was equippd with two operating tables each with an anaesthetoc machine, ECG monitor and oximeter. In mass casualey situations minor surgical operations were performed inot side room. As ventilation was so poor the use of inhaled ? agents would undoubtedly have caused significąt? pollution. After resuscitation and surgery, patients we evacuated by road to Split Clinical Hospital, if weathero conditions permitted. Total intravenous anaesthesia is suitable for many casualty scenarios, being simple, $\stackrel{\mathbb{Q}}{\stackrel{2}{2}}$ appropriate and adequate for surgery when a greater $\overrightarrow{\vec{F}}$ number of patients were admitted within a short period of 3 time. The method provided a good recovery profile and eased casualty evacuations.

Other workers have also confirmed the slower recovery profile seen in the thiopentone group (4). Except for the ketamine group where the systolic blood pressure was maintained, the arterial pressure decreased by about $15 \%$ after the induction of anaesthesia. In other groups there@ were no significant changes in pulse rates. Although $\vec{F}$ ketamine produces a tachycardia through centralo sympathetic stimulation, this effect can be abolished by the poor administration of midazolam (5). The absence of a major haemodynamic upset however could be attributed to the youth and physical state of the patients. Recovery from anaesthesia, was deemed to have occurred when the patient was able to give his name and year of birth. This was quickest in the propofol group and longest in the ketamine + midazolam group, possibly due to a syngergistic action of the two drugs $(6,7)$. Recovery from midazolam and ketamine anaesthesia can be accelerated ${ }^{\mathrm{\omega}}$ by the administration of flumazenil (8) or physostigmine 
(9). Apnoea of more than $20 \mathrm{sec}$ was recorded in $18 \%$ of the propofol alfentanyl group probably opioid (10-12). As there was no respiratory depression in this group, naloxone was not deemed necessary. Side effects such as vomiting were rare, but dreams, noted in the ketamine group were probably attenuated to the co-administration of midazolam. Although a total intravenous infusion using a combination of opioids, ketamine and propofol could provide cadiorespiratory stability for major cases when the lack of infusion pumps prohibited its use (13).

However for quick procedures in mass casualty scenarios in war the use of total intravenous techniques has been shown to be simple and effective.

Further work needs to be done in finding better drug combinations and extending the use of TIVA in longer procedures.

\section{REFERENCES}

1. Husar J, Eltz J. Mobile surgical teams in Croatian special forces unit (1990-1993). Guest editorial. Croat Med J 1993; 34: 274-6.

2. Lacković Z, Mrkuljéc I, Maruśić M. Croatian medicine in 1991 war against Croatia: A preliminary report. Croat Med J 1992; 33 (war suppl): 110-1.

3. Radonic V, ARAS N, PaVic A. Organization and functioning of the front-line surgical station at Rama in Bosnia and Herzegovina. Milit Med 1993; 12: 763-6.
4. Heath PJ, OgG TW, Gilus WR. Recovery after daycase anaesthesia. Anaesthesia 1990; 45: 911-5.

5. REVES JG, KISSEN I. Intravenous anaesthetics. In: Kaplan J. Cardiac Anaesthesia. New York: Grune \& Stratton, 1983:3.

6. DundeE JW. Twenty-five years of ketamine. Anaesthesia 1990; 45: 159-60.

7. White PF, Way WL, Trevor AJ. Ketamine - its pharmacology and therapeutic uses. Anaesthesiology 1982; 56: 119-36.

8. ARMSTRONG P, Watters J, Whitfield A. Flumazenil in ketamine and midazolam anaesthesia. Anaesthesia 1990; 45: 938-40.

9. Hamilton-Davies C, Bailie R, Restall J, Physostigmine in recovery from anaesthesia. Anaesthesia 1995; 50: 456-8.

10. MORGAN M. Total intravenous anaesthesia. Anaesthesia 1983; 38: 1-9.

11. Person MP, Nilsson A, Hartvig P. Pharmacokinetics of alfentanyl in total iv anaesthesia. Br J Anaesth 1988; 60: 755-61.

12. WiLSON RJ, RidLEy SA. The use of propofol and alfentanyl by infusion in military anaesthesia. Anaesthesia 1992; 47: 231-3.

13. Restall J, Tully AM, Kidd AG. Total intravenous anaesthesia for military surgery. A technique using ketamine, midazolam and vecuronium. Anaesthesia 1988; 43: 46-9. 